\title{
Inoculation of tomato plants with rhizobacteria enhances the performance of the phloem-feeding insect Bemisia tabaci
}

\author{
Roee Shavit ${ }^{1,2}$, Maya Ofek-Lalzar ${ }^{3}$, Saul Burdman ${ }^{2}$ and Shai Morin ${ }^{1 *}$ \\ ${ }^{1}$ Department of Entomology, The Robert H. Smith Faculty of Agriculture, Food and Environment, The Hebrew University of Jerusalem, Rehovot, Israel \\ 2 Department of Plant Pathology and Microbiology, The Robert H. Smith Faculty of Agriculture, Food and Environment, The Hebrew University of Jerusalem, \\ Rehovot, Israel \\ ${ }^{3}$ Department of Soil, Water and Environmental Sciences, Agricultural Research Organization of Israel, Bet Dagan, Israel
}

\section{Edited by:}

Ana Pineda, Wageningen University, Netherlands

Reviewed by:

Colette Broekgaarden, Wageningen

University, Netherlands

Inga Mewis, Leibniz-Institute for

Vegetable and Ornamental Sciences

Großbeeren/Erfurt e.V., Germany

\section{*Correspondence:}

Shai Morin, Department of

Entomology, The Robert H. Smith

Faculty of Agriculture, Food and

Environment, The Hebrew

University of Jerusalem, Building

707, PO Box 12, Rehovot 7610001,

Israel

e-mail:shai.morin@mail.huji.ac.il
In their natural environment, plants experience multiple biotic interactions and respond to this complexity in an integrated manner. Therefore, plant responses to herbivory are flexible and depend on the context and complexity in which they occur. For example, plant growth promoting rhizobacteria (PGPR) can enhance plant growth and induce resistance against microbial pathogens and herbivorous insects by a phenomenon termed induced systemic resistance (ISR). In the present study, we investigated the effect of tomato (Solanum lycopersicum) pre-inoculation with the PGPR Pseudomonas fluorescens WCS417r, on the performance of the generalist phloem-feeding insect Bemisia tabaci. Based on the ability of $P$. fluorescens WCS417r to prime for ISR against generalists chewing insects and necrotrophic pathogens, we hypothesized that pre-inoculated plants will strongly resist $B$. tabaci infestation. In contrast, we discovered that the pre-inoculation treatment increased the tomato plant suitability for $B$. tabaci which was emphasized both by faster developmental rate and higher survivability of nymph stages on pre-inoculated plants. Our molecular and chemical analyses suggested that the phenomenon is likely to be related to: (I) the ability of the bacteria to reduce the activity of the plant induced defense systems; (II) a possible manipulation by P. fluorescens of the plant quality (in terms of suitability for $B$. tabaci) through an indirect effect on the rhizosphere bacterial community. The contribution of our study to the pattern proposed for other belowground rhizobacteria and mycorrhizal fungi and aboveground generalist phloem-feeders is discussed.

Keywords: Bemisia tabaci, induced systemic resistance, plant growth promoting rizhobacteria, plant signaling, generalist phloem-feeders

\section{INTRODUCTION}

Plants rely both on constitutive and induced defenses in order to achieve optimal protection against their herbivorous enemies (Baldwin, 2001; Howe and Jander, 2008; Wu and Baldwin, 2010). These defenses can influence herbivore settling, feeding, oviposition, growth and development, fecundity, and/or fertility (Baldwin and Preston, 1999; Walling, 2000; Elsayed, 2011). Plant induced defenses involve activation of distinct signaltransduction pathways, in which three major plant hormonessalicylic acid (SA), jasmonic acid (JA) and ethylene (ET) are involved (Glazebrook, 2005; Bari and Jones, 2009; Pieterse et al., 2009).

The SA pathway is primarily activated in response to biotrophic pathogens, and regulates the expression of a wide array of defense-responses including the Pathogenensis-related protein (PR) coding genes (Ward et al., 1991; Van Loon and Van Strien, 1999; Van Loon et al., 2006). The JA/ET pathways are induced in response to necrotrophic pathogens and in response to wounding and tissue-damaging by insect feeding (Kessler and Baldwin, 2002; Kaloshian and Walling, 2005; Bari and Jones, 2009). JA and
ET can either cooperate or act as antagonists in the regulation of different stress responses (i.e., to pathogen attack or wounding) (Lorenzo and Solano, 2005). In the case of necrotrophic pathogens, both hormones cooperate or synergize in the activation of defense gene expression (Lorenzo et al., 2003). However, in the case of wound response, an antagonistic interaction between JA and ET has been described (Rojo et al., 1999). Two transcription factors, ERF1 and MYC2, have been shown to participate in the regulation of these interactions. ERF1 is induced by simultaneous action of the JA and ET signaling pathways, and plays a key role in the activation of plant defenses against necrotrophic pathogen infection by regulating defense-related genes, such as PDF1.2 (Lorenzo et al., 2003; Kazan and Manners, 2008). MYC2, on the other hand, is positively regulated by the abscisic acid (ABA) signaling pathway and functions as a transcriptional activator of genes (for example VSP2 in A. thaliana) in the MYC2-branch of the JA pathway, which is associated with plant responses to wounding or insect herbivory (Lorenzo et al., 2004; Dombrecht et al., 2007). Examples of JA/ET inducible proteins that have an established or putative role in direct plant 
defenses include: proteinase inhibitor (PI), polyphenol oxidase (PPO), arginase, threonine deaminase, leucine amino peptidase and acid phosphatase (Walling, 2000; Howe and Jander, 2008). SA and JA/ET signaling pathways can also mutually affect each other largely through negative cross-talk. This cross-talk helps the plant to minimize fitness costs and creates a flexible signaling network that allows the plant to fine-tune its defense response to the corresponding invaders (Kunkel and Brooks, 2002; Bostock, 2005).

Two forms of induced resistance that are systemically expressed in the plant, and effective against microbial pathogens and insect herbivores have been well-characterized: systemic acquired resistance (SAR), which is typically activated upon primary limited infection by a plant pathogen (Durrant and Dong, 2004); and induced systemic resistance (ISR), which is typically elicited by specific strains of non-pathogenic plant growthpromoting rhizobacteria (PGPR) or fungi (Van Loon et al., 1998). SAR is controlled by a signaling pathway that depends on endogenous accumulation of SA and the defense regulatory protein NPR1 (Durrant and Dong, 2004). As stated above, SAR is associated with the activation of $P R$ genes, some of which encode proteins with antimicrobial activity (Van Loon et al., 2006). On the other hand, the onset of ISR is not associated with enhanced expression of defense-related genes (Verhagen et al., 2004). In contrast, ISR is characterized by the establishment of a primed state for defense, in which defense-related responses are induced more rapidly upon pathogen or insect attack, thereby leading to a metabolically less costly state of resistance (Heil and Walters, 2009). The molecular mechanisms of ISR have been especially studied in Arabidopsis thaliana triggered by the rhizobacterium Pseudomonas fluorescens WCS417r, which indicated that PGPRmediated ISR is often associated with increased callose deposition at the site of pathogen entry and enhanced expression of JA/ETresponsive genes, such as PDF1.2 and VSP2 (Pieterse et al., 1996; Ahn et al., 2007; Van Oosten et al., 2008).

As JA is a key regulator of both ISR and plant defenses against herbivorous insects, it has been speculated that ISR induced by PGPR should benefit plants in their battle against insect herbivores. Indeed, studies with $A$. thaliana plants that were preinoculated with the PGPR P. fluorescens WCS417r showed that the growth and development of the generalist caterpillar Spodoptera exigua was negatively affected by the PGPR treatment. However, the negative effect of the PGPR-induced ISR was found not to be a general one, as no differences were observed between preinoculated and non-inoculated treatments in the growth and development of the specialist caterpillar Pieris rapae subjected to the same plant-PGPR system (Van Oosten et al., 2008). Recently, an additional level of complexity was added to our understanding of the rhizobacteria-herbivore insect systems as it was found that $P$. fluorescens WCS417r has a positive effect on the performance (weight gain and intrinsic rate of increase) of the generalist phloem-feeding aphid Myzus persicae on A. thaliana (Pineda et al., 2012). The same authors indicated that the observed aforementioned differential effects of rhizobacteria on herbivores, are in line with trends reported for mycorrhizal fungi (Gehring and Bennett, 2009; Koricheva et al., 2009), which were similarly shown to be dependent on the feeding-guild: negative effects on the development of generalist leaf-chewing insects and mesophyll feeders, neutral effects on specialist chewing and phloem-feeding insects, and un-predicted effects (negative, positive or neutral) on generalists phloem-feeding herbivores (De Vos et al., 2007a; Pineda et al., 2010; Valenzuela-Soto et al., 2010; Pineda et al., 2013).

In this study, we expanded this line of research by investigating the effect of $P$. fluorescens WCS417r on a second important generalist phloem-feeding model insect, the whitefly Bemisia tabaci (Hemiptera: Aleyrodidae). Bemisia tabaci is an important insect pest in many tropical and subtropical regions worldwide. It infests more than 600 plant species including important edible members of the Solanaceae family (Oliveira et al., 2001). Bemisia tabaci causes chlorosis on infested leaves, promotes the growth of sooty mold due to honeydew excretion (Schuster et al., 1996), and can transmit more than 200 species of plant viruses (Navas-Castillo et al., 2011). Like other phloem feeders, B. tabaci uses highly modified mouthparts (stylets) to intercellularly navigate through the plant cuticle, epidermis, and mesophyll and establish feeding sites in phloem sieve elements, causing comparatively little tissue damage (Tjallingii and Esch, 1993; Walker and Perring, 1994).

Our experimental system utilized tomato (Solanum lycopersicum) plants pre-inoculated with $P$. fluorescens WCS417r. We hypothesized that the relationship between the players in the B. tabaci-tomato- $P$. fluorescens system will add a general perspective to the complexity reported for the $M$. persicaeA. thaliana-P. fluorescens system (Pineda et al., 2012) due to two main reasons: (I) In A. thaliana, B. tabaci and likely other phloem feeders, are capable of manipulating plant-induced resistance (Zhu-Salzman et al., 2004; De Vos et al., 2007b; Kempema et al., 2007; Kusnierczyk et al., 2008). For example, B. tabaci infestation of $A$. thaliana plants was shown to induce the SAresponsive gene transcripts, while JA and ET-responsive gene transcripts were repressed or unchanged (Kempema et al., 2007). In contrast, $B$. tabaci feeding on plants like tomato and pepper (Solanaceae family), was shown to induce transcriptional changes in genes involved both in the JA/ET and SA pathways (ValenzuelaSoto et al., 2010; Yang et al., 2011); (II) Work with A. thaliana mutants indicated that $B$. tabaci is likely to be highly susceptible to JA-defenses, as mutants that activate JA defenses (cev1) or impair SA defenses (npr1, NahG) slowed B. tabaci nymphal development (Zarate et al., 2007).

Our hypothesis was tested through three main approaches: First, we determined if pre-inoculation of tomato plants with $P$. fluorescens WCS417r alters B. tabaci developmental and reproductive performance. Second, we examined the effect of preinoculation of tomato plants with $P$. fluorescens on the basal and induced expression levels of the JA/ET and SA defense pathways, before and during 12 days of $B$. tabaci infestation. Third, we determined the effect of pre-inoculation with P. fluorescens on tomato plant nutritional quality and the microbial composition of the rhizosphere.

\section{MATERIALS AND METHODS PLANT MATERIAL}

Seeds of tomato plants (Solanum lycopersicum cv. H7998) were sown in sowing tray containing soil mixture (Tuff Merom Golan) 
that was autoclaved twice with a $24 \mathrm{~h}$ interval. After root inoculation, seedlings were transferred to $11 \mathrm{~cm}$ diameter pots containing the same soil mixture. Plants were maintained in Plexiglas cages with 50 mesh nets under growing conditions of $26 \pm 2{ }^{\circ} \mathrm{C}$ and long-day photoperiod conditions (L:D $14 \mathrm{~h}: 10 \mathrm{~h}$ ).

\section{INSECT REARING}

The B. tabaci Asia Minor-Middle East 1 (B) colony was collected from a melon field at the western Negev of Israel in 2003. Since its collection, the colony was maintained in the laboratory on Acala cotton (Gossypium hirsutum L cv. Acala), without exposure to insecticides, under standard greenhouse conditions of 14:10 L:D photoperiod, $26 \pm 2{ }^{\circ} \mathrm{C}$. The homogeneity and purity of the colony was verified every $2-3$ generations by cleaved amplified polymorphic sequences (CAPS) of the COI gene (Khasdan et al., 2005).

\section{BACTERIAL INOCULATION}

Pseudomonas fluorescens WCS417r (Pieterse et al., 1996) was grown for $48 \mathrm{~h}$ at $28^{\circ} \mathrm{C}$ on King's medium B (King et al., 1954) supplemented with $25 \mu \mathrm{g}$ of rifampicin per milliliter. Bacteria were collected and re-suspended in $0.1 \mathrm{M} \mathrm{MgSO}_{4}$ to achieve a final density of $10^{8} \mathrm{CFU} \mathrm{m} \mathrm{m}^{-1}\left(\mathrm{OD}_{660}=0.1\right)$. Two-weeks-old tomato seedlings in sowing trays were dipped into the bacterial solution for $2 \mathrm{~h}$. Control plants were dipped into $0.1 \mathrm{M} \mathrm{MgSO}_{4}$ solution. Two days post inoculation, seedlings were transferred into pots. After 1 week, inoculated plants were watered with $25 \mathrm{ml}$ of bacterial solution while control plants were watered with $0.1 \mathrm{M}$ $\mathrm{MgSO}_{4}$ solution.

\section{Bemisia tabaci REPRODUCTIVE PERFORMANCE ASSAYS}

All B. tabaci reproductive performance experiments were conducted in a temperature-controlled room (L:D 14 h:10 h, $26 \pm$ $2^{\circ} \mathrm{C}$ ). Twelve adult couples (male and female), $72 \mathrm{~h}$ after emergence, were collected into a clip cage, $3 \mathrm{~cm}$ in diameter, which was attached to the third true leaf of 3-4-week-old pre-inoculated or non-inoculated (control) tomato plants. Plants were inoculated with $P$. fluorescens WCS417r 2 weeks earlier, while non-inoculated plants were treated with $0.1 \mathrm{M} \mathrm{MgSO}_{4}$ solution. After a $24 \mathrm{~h}$ oviposition period, all adults were collected and eggs were allowed to develop for 17 days. The number of eggs on each leaf was recorded 5 days after infestation. The total number of progeny, their developmental stages (second through early fourth nymphs, late fourth nymphs, empty exuvia indicating emergence), and viability status (live/dead), were recorded after 17 days. The developmental rate was estimated by calculating the proportion of 1st-early 4 th nymphs, late fourth nymphs (red-eye yellow 4th nymph) and empty exuvia on each plant, 17 days after infestation. The survival rate was calculated as the proportion of live nymphs from the total number of eggs oviposited on each plant. Each treatment was replicated $\sim 30$ times in three independent experiments. Differences in development (for each stage separately) and survival rates of $B$. tabaci between pre-inoculated and noninoculated tomato plants were analyzed using a generalized linear model with a logit link and a binomial distribution. Difference in oviposition was tested for significance using a generalized linear model with a Poisson distribution and the logarithmic link function. Statistical significance was assumed at $p=0.05$. All statistical analyses conducted in this paper (see below) were performed with JMP statistical software version 7.0.1 (SAS Institute, USA).

\section{EXPRESSION OF JA/ET- AND SA-REGULATED DEFENSE GENES}

To determine if pre-inoculation of tomato plant roots with $P$. $f l u$ orescens WCS417r modifies the plant induced systemic defenses toward B. tabaci infestation, we quantified, by quantitative realtime PCR (qRT-PCR), the expression level of JA/ET pathway gene markers Proteinase inhibitor I and II (PI-I and PI-II, respectively) (Puthoff et al., 2010; Abd El Rahman et al., 2012) and the SA pathway gene markers Pathogenesis-related protein 2 and 5 (PR2 and PR-5, respectively) (Van Loon et al., 2006). The list of gene names, qRT-PCR primers and product sizes is provided in Table A1. In order to be capable of separating the bacterial effect from that of insect infestation, four different treatments were applied: (I) control plants, not inoculated with $P$. fluorescens and without B. tabaci infestation (P-/B- plants); (II) P. fluorescens preinoculated plants without $B$. tabaci infestation $(\mathrm{P}+/ \mathrm{B}-$ plants); (III) non-inoculated plants with $B$. tabaci infestation $(\mathrm{P}-/ \mathrm{B}+$ plants); (IV) P. fluorescens pre-inoculated plants with $B$. tabaci infestation $(\mathrm{P}+/ \mathrm{B}+$ plants $)$. Experiments were conducted in a temperature-controlled room (L:D 14 h:10 h, $26 \pm 2^{\circ} \mathrm{C}$ ). Preinoculation and infestation protocols were identical to the ones described above. Non-inoculated plants were treated with $0.1 \mathrm{M}$ $\mathrm{MgSO}_{4}$ solution. An empty clip cage was attached to the third true leaf of 3-4-week-old un-infested plants.

Total RNA was extracted from $100 \mathrm{mg}$ of third leaf tissue of plants that received one of the four aforementioned treatments. Samples were collected at four time points, representing different stages in the plant-insect-interaction cycle: prior to infestation ("day 0"-control), and one ("day 1"- the effect of $24 \mathrm{~h}$ of adults" feeding and egglaying), six ("day 6"-the beginning of egg hatching in which minimal effect of B. tabaci infestation is expected) and twelve ("day 12"-presence of B. tabaci 2nd and 3rd feeding nymphs - the effect of nymph infestation) days after B. tabaci infestation. Uninfested plants were treated in a similar way, and leaf samples were collected at the same time points as the B. tabaci-infested treatments. Three separate biological replicates were performed for each treatment in each of three independent experiments (total of 9 replicates per treatment). Each replicate consisted of one leaf from one plant that was sampled only once, in order to avoid the subsequent interfering effects of plant damage during leaf collection. Immediately after collection, leaf tissues were placed in liquid nitrogen and grounded by a tissuelyzer (Qaigen). RNA was extracted using Trizol reagent (Invitrogen), according to the manufacturer's instructions. RNA concentration and purity was measured by NanoDrop ND-100 (NanoDrop Technologies, USA) and $1 \mu \mathrm{l}$ of $40 \mathrm{u} / \mu \mathrm{l}$ RNase inhibitor (Fermentas) was added to prevent RNA degradation. Two micrograms of total RNA were treated with DNase (Sigma) and RNA was stored at $-80^{\circ} \mathrm{C}$. cDNA synthesis was performed on $1 \mu \mathrm{g}$ of total RNA using reverse transcriptase revertAID $\mathrm{H}$ minus (Ferments) and OligodT primer ( $5^{\prime}$ TTTTTTTTTTTTTTTTTTTV $3^{\prime}$ ), according to manufacturer's instructions. 
qRT-PCR reactions were performed using ABI 7300 (Applied Biosystems). Each reaction was optimally set to a master mix (18 $\mu \mathrm{l}$ ) containing: $2 \mu \mathrm{l}$ of cDNA, $150 \mathrm{nM}$ of forward and reverse primers, $4.3 \mu \mathrm{l}$ distilled deionized water (DDW) and $9 \mu \mathrm{l}$ of Platinum SYBR Green qPCR SuperMix (invitrogen). PCR thermal conditions consisted of one cycle of $50^{\circ} \mathrm{C}$ for $2 \mathrm{~min}$, one cycle of $95^{\circ} \mathrm{C}$ for $2 \mathrm{~min}$, followed by 40 cycles of $95^{\circ} \mathrm{C}$ for $15 \mathrm{~s}$ and $60^{\circ} \mathrm{C}$ for $30 \mathrm{~s}$. All the primers in this study were calibrated and adjusted to reaction conditions and showed slop values of 3.3-3.6 and $R^{2} \geq$ 0.98 in calibration curves. Reaction results were analyzed with the 7300 System SDS Software (Applied Biosystems). Quantification of the transcript levels were conducted according to the $\triangle \mathrm{CT}$ method (Yuan et al., 2006) using cyclopilin (CYP) from tomato as the reference gene (Mascia et al., 2010). To minimize intraexperimental variation, each reaction was performed in triplicate of which $\Delta \mathrm{CT}$ was calculated. Two negative controls were added to each reaction, a non-template control and a non-amplicon control (-RT control). Normalized $\Delta \Delta \mathrm{CT}$ values were calculated by subtracting the mean $\Delta \mathrm{CT}$ value of the $\mathrm{P}-/ \mathrm{B}-$ samples (see above) from the $\Delta \mathrm{CT}$ values of the $\mathrm{P}+/ \mathrm{B}+, \mathrm{P}+/ \mathrm{B}-, \mathrm{P}-/ \mathrm{B}+$ and $\mathrm{P}-/ \mathrm{B}-$ samples within each time point and experiment combination. This normalization was required both for excluding the effect of plant age on defense gene expression and for reducing the variance between experiments. Differences in $\Delta \Delta C T$ values were tested for significance by a Three-Way ANOVA model, in which bacteria $(\mathrm{P}+$ or $\mathrm{P}-)$, insect $(\mathrm{B}+$ or $\mathrm{B}-)$ and time period $(0,1,6$ or 12 days) were set as fixed effects. Specific means in the (bacteria $\mathrm{X}$ insect) interaction were selected $a$ priori and orthogonal comparisons were conducted within each time period. Statistical significance was assumed at $p \leq 0.05$.

\section{CARBOHYDRATE EXTRACTION AND QUANTIFICATION}

Carbohydrate extraction was performed on tomato leaves, 2 weeks after $P$. fluorescens inoculation. Control plants were treated at the same time with $0.1 \mathrm{M} \mathrm{MgSO}_{4}$ solution. Third true leaf tissue material $(100 \mathrm{mg}$ ) was placed in liquid nitrogen, grounded by a tissuelyzer (Qiagen) and extracted in $5 \mathrm{ml} 80 \%(\mathrm{v} / \mathrm{v})$ ethanol $\left(30 \mathrm{~min}, 30^{\circ} \mathrm{C}\right)$. The extract was centrifuged $(10 \mathrm{~min}$, $2150 \times \mathrm{g})$ and the pellet was extracted again with ethanol. After centrifugation, chlorophyll was removed from the soluble sugar supernatants by chloroform extraction. Samples were analyzed colorimetrically for soluble carbohydrates using the anthrone method (Yemm and Willis, 1954). Differences in soluble carbohydrate concentrations ( $\mathrm{mg} / \mathrm{g}$ leaf fresh weight) were tested for significance by a Two-Way ANOVA II model. Bacterial treatment was set as a fixed effect while experiment was set as a random effect. Statistical significance was assumed at $p \leq 0.05$.

\section{QUANTIFICATION OF CARBON (C) AND NITROGEN (N) CONTENTS}

Quantifications of $\mathrm{C}$ and $\mathrm{N}$ contents were performed on two tissue sources: (I) tomato third true leaves, 2 weeks after $P$. $f l u$ orescens inoculation. Control non-inoculated plants were treated at the same time with $0.1 \mathrm{M} \mathrm{MgSO}_{4}$ solution. (II) Two hundred B. tabaci adults, 6 days after they infested P. fluorescens pre-inoculated plants or non-inoculated control plants. $\mathrm{C}$ and $\mathrm{N}$ contents were measured on samples of $2 \mathrm{mg}$ dried and ground tissues $\left(60^{\circ} \mathrm{C}, 48 \mathrm{~h}\right)$ using an elemental analyzer (Thermo-Electron
Flash EA 1112) equipped with a copper/copper oxide column and a thermal conductivity detector. Differences in $\mathrm{C}$ and $\mathrm{N}$ contents (\%) and $\mathrm{C} / \mathrm{N}$ ratio were tested for significance (independently for plant and insect tissues) by a Two-Way ANOVA II model. Bacterial treatment was set as a fixed effect while experiment was set as a random effect. Statistical significance was assumed at $p \leq 0.05$.

\section{RHIZOBACTERIUM DNA EXTRACTION AND DENATURING GRADIENT GEL ELECTROPHORESIS (DGGE)}

Rhizobacterium samples were collected from $0.2 \mathrm{~g}$ of soil that remained attached to the roots of the tomato plants after vigorous shaking. Samples were collected from four different treatments: (I) control plants, not inoculated with $P$. fluorescens and without B. tabaci infestation ( $\mathrm{P}-/ \mathrm{B}-$ "day 0" samples); (II) $P$. fluorescens pre-inoculated plants without $B$. tabaci infestation (P+/B- "day 0" samples); (III) non-inoculated plants after 12 days of $B$. tabaci infestation ( $\mathrm{P}-/ \mathrm{B}+$ "day 12" samples); (IV) P. fluorescens pre-inoculated plants after 12 days of $B$. tabaci infestation ( $\mathrm{P}+/ \mathrm{B}+$ "day 12" samples). Three separate biological replicates were performed for each treatment. DNA extraction was conducted according to the manufacturer's instructions, using the Power Soil extraction kit (MoBio Laboratories, Inc., Carlsbad, CA) with one modification: to increase DNA concentration, the elution volume was set to 40 instead of $100 \mu \mathrm{l}$. The forward GC-clamp $968 \mathrm{~F}$ and reverse 1401R primers, amplifying a $\sim 450$ bp product of bacterial $16 \mathrm{~S}$ rRNA, were used in the PCR reactions (see primer's list in Table A1). PCR mixtures contained $10 \mu \mathrm{l}$ Red load Taq master (Larova), $2 \mu \mathrm{l}$ of each primer $(10 \mathrm{pmol} / \mu \mathrm{l}), 3 \mu \mathrm{l}$ template DNA and double-distilled water to a final volume of $50 \mu \mathrm{l}$. PCR thermal conditions consisted of denaturation at $94^{\circ} \mathrm{C}$ for $3 \mathrm{~min}, 35$ cycles of $94^{\circ} \mathrm{C}$ for $30 \mathrm{~s}, 57^{\circ} \mathrm{C}$ for $30 \mathrm{~s}$, and $72^{\circ} \mathrm{C}$ for $1 \mathrm{~min}$, followed by $10 \mathrm{~min}$ at $72^{\circ} \mathrm{C}$ as an ending step. The presence of bacterial DNA products was verified by gel electrophoresis using $1 \%(\mathrm{w} / \mathrm{v})$ agarose, stained with ethidium bromide $(0.2 \mathrm{mg} / \mathrm{ml})$. Denaturing gradient gel electrophoresis (DGGE) was performed according to Green et al. (2009). PCR products were loaded on a denaturing gradient gel containing $6 \%(\mathrm{w} / \mathrm{v})$ polyacrylamide gel [acrylamide/bisacrylamide (37:1)] in $1 \mathrm{X}$ Tris-acetate-EDTA (TAE) buffer with a $50-65 \%$ denaturing gradient $(50-18 \%(\mathrm{v} / \mathrm{v})$ formamide and $4.37 \mathrm{M}$ urea, 65-26\% (v/v) formamide and $5.86 \mathrm{M}$ urea). Electrophoresis was performed with a Phor-U2 system (Ingeny, Goes, Holland) in $1 \mathrm{X} \mathrm{TAE}$ at $60^{\circ} \mathrm{C}, 95 \mathrm{~V}$ for $16 \mathrm{~h}$. The gels were stained for $45 \mathrm{~min}$. using $40 \mu \mathrm{l}$ of Gel star (Lonza) in $300 \mathrm{ml} 1 \mathrm{X}$ TAE, followed by $15 \mathrm{~min}$. rinsing in $1 \mathrm{X}$ TAE. Visualization was performed using the AlphaImageri System (Alpha Innotech Corporation, California, USA). DGGE patterns were aligned using Fingerprinting ${ }^{\circledR}$ II software and the samples' densitometric curves were calculated. Analysis of similarity (ANOSIM) based on the Bray-Curtis distance matrix, calculated between the samples densitometric curves was performed. In addition, unweighted pair-group method with arithmetic mean (UPGMA) algorithm was applied to a Bray-Curtis distance matrix. Bootstrap values were calculated after running 10,000 replications. Analyses were conducted using the PAST software (http://folk.uio.no/ohammer/past/). 


\section{RESULTS}

REPRODUCTIVE PERFORMANCE OF $B$. tabaci ON P. fluorescens WCS417r PRE-INOCULATED AND NON-INOCULATED TOMATO PLANTS

Bemisia tabaci infestation was conducted 14 days after P. fluorescens WCS417r inoculation. At this time, the bacterial concentration in tomato roots was $\sim 2.6 \times 10^{5} \mathrm{CFU} / \mathrm{g}$ freshroots. Estimations of two independent life-history traits related to reproduction indicated increased nymphs performance on $P$. fluorescens pre-inoculated plants relative to non-inoculated control plants. Both the nymph survival rate and the proportion of progeny that emerged as adults, 17 days after oviposition, were significantly higher on pre-inoculated plants $\left[\chi_{(1)}^{2}=4.16, p=0.041\right.$ and $\chi_{(1)}^{2}=11.09, p=0.0009$, respectively] (Figures 1A,B). Although the number of oviposited eggs was also higher on pre-inoculated plants than on non-inoculated plants, this difference was not significant $\left[\chi_{(1)}^{2}=1.68, P=0.19\right]$ (Figure 1C).

Collectively, our performance experiments indicated that tomato plants, pre-inoculated with $P$. fluorescens WCS417r, are likely to be a more suitable host for $B$. tabaci than noninoculated plants. In order to try gaining insight into this finding, we further explored three possibilities: (I) that preinoculated and non-inoculated plants differ in the activity levels of their induced resistance pathways; (II) that the two plant types differ in their nutritional status; (III) that $P$. fluorescens pre-inoculation manipulates the plant's quality (in terms of suitability for $B$. tabaci) through an indirect effect on the rhizosphere bacterial community.

\section{CHARACTERIZING THE MOLECULAR ACTIVITY OF THE JA/ET AND SA PATHWAYS IN TOMATO PLANTS PRE-INOCULAED AND NON-INOCULATED WITH $P$. fluorescens WCS417r}

qRT-PCR analyses were done to quantify the transcript levels of four marker genes: $P I-I$ and $P I-I I$ (JA/ET-responsive genes) and $P R-2$ and $P R-5$ (SA-responsive genes) following $P$. fluorescens pre-inoculation or non-inoculation treatments. Analyses were conducted at four time points, representing different stages in the plant-insect-interaction cycle: "day 0" (before B. tabaci infestation), "day 1" (the effect of $24 \mathrm{~h}$ of adults' feeding and egglaying), "day 6" (the beginning of egg hatching in which minimal effect of $B$. tabaci infestation is expected) and "day 12" (presence of B. tabaci 2nd and 3rd feeding nymphs - the effect of nymph infestation) after B. tabaci infestation.

A striking phenomenon that was shared by all four genes analyzed, was the general lower activity levels of both the JA/ET and SA pathways in $P$. fluorescens pre-inoculated plants. This main effect was significant for the PI-II, PR-2 and PR-5 genes $(p \leq 0.040)$ and marginally significant also for $P I-I(p=0.063)$. The main effect of "time" was also highly significant for all four genes $(p \leq 0.036$ ). All four genes (responding to the JA/ET or SA pathways) were significantly up-regulated at "day 1 ," when compared to their expression levels at "day 6" ( $p \leq 0.040)$, and the $P R-2$ and $P R-5$ genes were also significantly up-regulated at "day 1" when compared to "day 12" ( $p \leq 0.0001)$. None of the four genes significantly differed in their expression levels between "day 6" and "day 12" although the PI-I, PI-II (up-regulated) and $P R-5$ (down-regulated) genes were on the boarder of significance ( $p=0.078, p=0.094$ and $p=0.057$, respectively). In contrast, the main effect of "insect infestation" was found to be significant for only one gene marker ( $P I-I I, p \leq 0.008)$, where the expression level was higher in infested plants. Main effect statistical details are presented in Table A2.

Detailed analyses were conducted for each infestation period separately (summarized in Table 1; see Material and Methods for explanation on the four combinations of $P$. fluorescens $\mathrm{WCS} 417 \mathrm{r}$ and $B$. tabaci treatments: $\mathrm{P}-/ \mathrm{B}-, \mathrm{P}+/ \mathrm{B}-, \mathrm{P}-/ \mathrm{B}+$ and $\mathrm{P}+/ \mathrm{B}+)$. At "day 0," no differences were observed, in the expression levels of all four analyzed genes, between the $\mathrm{P}-/ \mathrm{B}-$ and $\mathrm{P}+/ \mathrm{B}-$ tomato plants $(p \geq 0.20)$. At "day 1 ," the expression levels of the $P R-2$ and $P R-5$ genes were significantly up-regulated in the $(\mathrm{P}-/ \mathrm{B}+)$ treatment when compared to the $\mathrm{P}-/ \mathrm{B}-$ treatment ( $p=0.008$ and $p=0.020$, respectively), while the PI-I and PI-II genes showed similar non-significant trends $(p=0.095$ and $p=$ 0.14 , respectively). In contrast, no differences were observed between the four genes' expression levels in the $\mathrm{P}+/ \mathrm{B}-$ and $\mathrm{P}+/ \mathrm{B}+$ treatments $(p \geq 0.28)$, indicating that rhizobacteria colonization can likely reduce $B$. tabaci-dependent up-regulation of both SA- and JA/ET-responsive genes. The main finding at "day 6 " was the reduced activity of both $P I-I I$ and $P R-2(p=0.037$ and $p=0.017$, respectively) in the $\mathrm{P}+/ \mathrm{B}+$ treatment when compared to the $\mathrm{P}-/ \mathrm{B}+$ treatment. In addition, a similar non-significant trend was observed in the expression pattern of PI-I $(p=0.20)$. $P I-I I$ also showed marginally-significant reduced expression-level
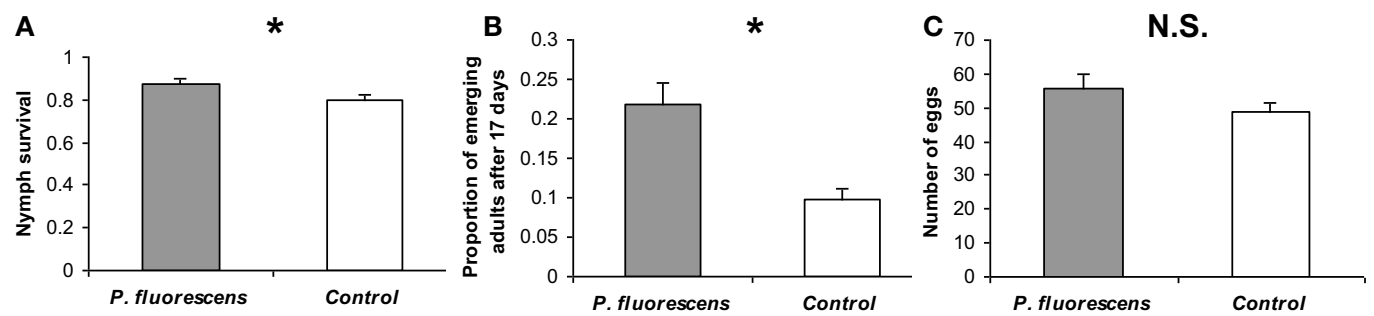

FIGURE 1|Reproductive performance of $B$. tabaci on P. fluorescens WCS417r pre-inoculated and non-inoculated tomato plants. (A) The proportion of live nymphs from the total number of eggs oviposited. (B) The proportion of progeny that had emerged as adults by day 17. (C) The mean number of eggs oviposited by 12 females during $24 \mathrm{~h}$. Asterisks indicate significant differences $(P \leq 0.05)$. Errors bars represent standard error of the means $(n=\sim 30)$. N.S. $=$ Not significant. 
Table 1 | Transcriptional profiles of four gene markers: $P I-I$ and $P I-I I$ (JA/ET-responsive genes) and $P R-2$ and $P R-5$ (SA-responsive genes) in P. fluorescens pre-inoculation $(\mathrm{P}+)$ and non-inoculated $(\mathrm{P}-)$ tomato plants, with or without (control) $B$. tabaci infestation $(\mathrm{B}+$ and $\mathrm{B}-$, respectively).

\begin{tabular}{|c|c|c|c|c|c|c|c|c|c|c|c|c|c|c|}
\hline \multirow[t]{2}{*}{ Gene } & \multicolumn{2}{|c|}{ “Day 0" } & \multicolumn{4}{|c|}{ “Day 1" } & \multicolumn{4}{|c|}{ "Day 6" } & \multicolumn{4}{|c|}{ "Day 12" } \\
\hline & $\mathrm{P}-/ \mathrm{B}-$ & $\mathrm{P}+/ \mathrm{B}-$ & $\mathrm{P}-/ \mathrm{B}-$ & $\mathrm{P}-/ \mathrm{B}+$ & $\mathrm{P}+/ \mathrm{B}-$ & $\mathrm{P}+/ \mathrm{B}+$ & $\mathrm{P}-/ \mathrm{B}-$ & $\mathrm{P}-/ \mathrm{B}+$ & $\mathrm{P}+/ \mathrm{B}-$ & $\mathrm{P}+/ \mathrm{B}+$ & $\mathrm{P}-/ \mathrm{B}-$ & $\mathrm{P}-/ \mathrm{B}+$ & $\mathrm{P}+/ \mathrm{B}-$ & $\mathrm{P}+/ \mathrm{B}+$ \\
\hline Pl-I & 1.00 & 1.05 & 1.00 & 2.50 & 1.21 & 1.33 & $1.19 b$ & $0.53 \mathbf{a b}$ & $0.53 \mathbf{a b}$ & $0.22 \mathbf{a}$ & 1.00 & 1.07 & 0.66 & 0.88 \\
\hline Pl-II & 1.00 & 0.72 & 1.00 & 4.37 & 1.24 & 3.64 & $1.00 \mathbf{a b}$ & $1.66 \mathbf{b}$ & $0.12 \mathbf{a}$ & $0.16 \mathbf{a}$ & $1.00 \mathbf{a b}$ & $3.61 \mathbf{b}$ & $0.12 \mathbf{a}$ & $4.50 b$ \\
\hline PR-2 & 1.00 & 1.89 & $1.00 \mathbf{a}$ & $4.45 b$ & $1.95 \mathbf{a b}$ & $1.93 \mathbf{a b}$ & $1.00 \mathbf{a b}$ & $1.17 b$ & $0.64 \mathbf{a b}$ & $0.52 \mathbf{a}$ & 0.7 & 0.84 & 0.44 & 0.52 \\
\hline$P R-5$ & 1.00 & 0.63 & $1.00 \mathbf{a}$ & $5.44 b$ & $0.99 \mathbf{a}$ & $1.61 \mathbf{a b}$ & 1.00 & 0.94 & 0.31 & 0.93 & 1.00 & 0.26 & 0.19 & 0.23 \\
\hline
\end{tabular}

Samples were collected at four time points: "day 0" (prior to B. tabaci infestation and egglaying), "day 1" (the effect of 24h of adults' infestation and egglaying),

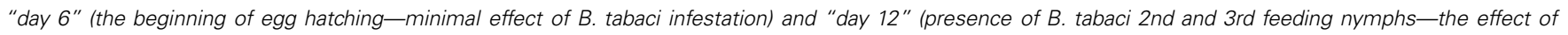
nymph infestation). Numbers indicate relative expression levels $\left(2^{-\Delta \Delta} C T\right)$. Normalized $\Delta \Delta C T$ values were calculated by subtracting the mean $\Delta C T$ value of the $P-/ B-$ samples (see above) from the $\Delta C T$ values of the $P-/ B+, P+/ B-, P+/ B+$ and $P-/ B-$ samples within each time point and experiment combination. Different letters and gray shading (light vs. dark) within each time point and gene combination, indicate significant differences between the treatments ( $\leq \leq 0.05)$.

Table 2 | The levels of soluble carbohydrates, $\mathrm{N}$ (nitrogen) and C (carbon) in P. fluorescens WCS417r pre-inoculated and non-inoculated plants.

\begin{tabular}{|c|c|c|c|c|}
\hline Plant treatment & \multicolumn{4}{|c|}{ Nutritional content } \\
\hline Control & $2.14 \pm 0.12$ & $6.27 \pm 0.06$ & $42.82 \pm 0.54$ & $6.83 \pm 0.12$ \\
\hline$P$-value & 0.047 & 0.035 & 0.023 & 0.60 \\
\hline
\end{tabular}

FW, fresh weight; DW, dry weight; SE, standard error. Differences were tested for significance by a Two-Way ANOVA II model. Statistical significance was assumed at $P \leq 0.05$.

in the $\mathrm{P}+/ \mathrm{B}-$ treatment when compared to the $\mathrm{P}-/ \mathrm{B}-$ treatment $(p=0.07)$, indicating a putative general reduced activity of the JA/ET pathway in $P$. fluorescens pre-inoculated plants at this time point. At "day 12," non-significant differences were observed between the four treatment combinations of $P$. fluorescens and B. tabaci when the expression levels of the PI-I, PR-2 and PR-5 genes were compared ( $p \geq 0.09$ ). In contrast, the expression level of the $P I-I I$ gene was significantly up-regulated in the $B$. tabaci infested treatments $(\mathrm{P}-/ \mathrm{B}+$ and $\mathrm{P}+/ \mathrm{B}+)$ when compared to the $\mathrm{P}+/ \mathrm{B}-$ treatment $(p=0.032$ and $p=0.022$, respectively), indicating the strong induced expression of the JA/ET pathway, during long period of $B$. tabaci infestation.

\section{PLANT AND INSECT NUTRIENT CONTENTS}

In these experiments, we measured the levels, in P. fluorescens preinoculated and non-inoculated plants, of three chemicals thought to be important nutrients for arthropod herbivores: soluble carbohydrates, $\mathrm{N}$ (nitrogen), and $\mathrm{C}$ (carbon). $\mathrm{N}$ and $\mathrm{C}$ contents were also measured in B. tabaci adults, after 6 days of feeding on preor non-inoculated plants. Soluble carbohydrate concentrations and $\mathrm{N}$ and $\mathrm{C}$ contents were determined in dried and ground material of third true leaves. Pre-inoculated plant leaf tissues contained significantly more soluble carbohydrates $\left[F_{(1,47)}=\right.$ $4.15, p=0.047$ ] (Table 2) than non-inoculated plants. In contrast, both $\mathrm{N}$ and $\mathrm{C}$ contents were significantly higher in noninoculated plants than in pre-inoculated plants $\left[F_{(1,10)}=5.92\right.$, $p=0.035$ and $F_{(1,9)}=7.56, P=0.022$, respectively] (Table 2). Consequently, the $\mathrm{C} / \mathrm{N}$ ratios were found to be similar in
Table 3 | The N (nitrogen), and C (carbon) contents of B. tabaci adults, after 6 days of feeding on P. fluorescens WCS417r pre- or non-inoculated plants.

\begin{tabular}{llll}
\hline Plant treatment & \multicolumn{3}{c}{ Nutritional Content } \\
\cline { 2 - 4 } & N \% (DW \pm SE) & C \% (DW \pm SE) & C/N Ratio \\
\hline P. fluorescens WCS417r & $9.60 \pm 0.15$ & $53.05 \pm 0.37$ & $5.53 \pm 0.07$ \\
Control & $9.34 \pm 0.03$ & $52.88 \pm 0.53$ & $5.66 \pm 0.06$ \\
$P$-value & 0.20 & 0.52 & 0.13 \\
\hline
\end{tabular}

$D W$, dry weight; SE, standard error. Differences were tested for significance by a Two-Way ANOVA I/ model. Statistical significance was assumed at $P=0.05$.

pre- and non-inoculated tomato plants $\left[F_{(1,10)}=0.29, p=0.60\right]$ (Table 2). No significant differences were detected in the $\mathrm{N}$ and $\mathrm{C}$ contents and their $\mathrm{C} / \mathrm{N}$ ratio, between $B$. tabaci adults that fed for 6 days on pre- and non-inoculated tomato plants $(p \geq 0.13)$ (Table 3).

\section{DGGE PROFILE OF BACTERIAL COMMUNITIES IN THE TOMATO RHIZOSPERE}

The DGGE profiles of the bacterial communities of the tomato rhizosphere were analyzed by calculating the samples' densitometric curves. The P. fluorescens WCS417r bacteria sample, inserted as a control strain, could not be associated with high confidence, with any of the observed profiles, likely due to the low relative abundance of these bacteria $\left(\sim 2.6 \times 10^{5} \mathrm{CFU} / \mathrm{g}\right.$ freshroots) in the rhizosphere bacterial community. The ANOSIM test, 
performed on the densitometric curve matrix, indicated significant effects for the "time" ("day 0" or "day 12") and "bacteria" (pre-inoculated or non-inoculated) treatments $(p=0.0004$ and $p=0.015$, respectively) but not for the "insect" (infested or uninfested) treatment $(p=0.38)$. Cluster analysis (UPGMA algorithm applied to the Bray-Curtis distance matrix) using 10,000 bootstrap repetitions, robustly divided the 18 samples (with two exceptions) into three main groups (Figure 2): group I contained the $\mathrm{P}-/ \mathrm{B}-$ "day 0 " samples with similarity $\geq 93.3 \%$; group II was formed by two clusters, one of $\mathrm{P}+/ \mathrm{B}-$ "day 0 " samples with similarity of $\geq 94.1 \%$, and the other of the $\mathrm{P}+/ \mathrm{B}-$ "day 12 " and $\mathrm{P}+/ \mathrm{B}+$ "day 12 " samples with similarity $\geq 93.7 \%$; group III contained $\mathrm{P}-/ \mathrm{B}+$ and $\mathrm{P}-/ \mathrm{B}-$ "day 12 " samples, with similarity $\geq$ 94.9\%.

\section{DISCUSSION}

In the current study, we investigated the effects of pre-inoculation of tomato plants with the PGPR P. fluorescens WCS417r, on the performance of a generalist phloem-feeding model insect, the whitefly Bemisia tabaci. Based on the reported susceptibility of B. tabaci to JA-dependent defenses (Zarate et al., 2007) and the ability of $P$. fluorescens WCS417r to prime for enhanced JA-dependent resistance against generalists chewing insects (Van Oosten et al., 2008) and necrotrophic pathogens (Pieterse et al., 1998), we hypothesized that $P$. fluorescens WCS417r preinoculated tomato plants will resist $B$. tabaci infestation by strong expression of JA-responsive genes upon insect attack. On the contrary, our findings indicated a positive effect of pre-inoculation on $B$. tabaci performance, which was emphasized both by faster developmental rate and higher survivability of nymph stages on pre-inoculated plants. These unexpected findings are in-line with an independent study, published during our research, which reported that strain WCS417r has a positive effect on the performance (weight gain and intrinsic rate of increase) of the generalist aphid M. persicae when feeding on A. thaliana (Pineda et al., 2012). Collectively, these studies suggest a possible generalized positive relationship between $P$. fluorescens WCS417r and generalist phloem-feeders which is independent of the plant host.

Why do generalist phloem feeders respond differently than other insect herbivores to pre-inoculation of plant hosts with $P$. fluorescens WCS417r? Three possible explanations already exist in the literature. First, phloem feeders in general and B. tabaci in particular, are known to cause minimal damage to plant tissues while feeding (Johnson and Walker, 1999). This might enable them to avoid both constitutive and PGPR-primed induced plant-defense systems that require tissue damage (Kaloshian and Walling, 2005; Walling, 2008). Second, phloem feeders experience only plant defensive compounds that are translocated through the phloem, and are only marginally affected by those expressed in other tissues (Ramsey et al., 2010). Third, in A. thaliana, accumulating evidence suggest that phloem feeding insects such as aphids and whiteflies, can manipulate plant-induced resistance and are able to suppress effective JA defenses by the induction of the inefficient SA signaling-based responses (De Vos et al., 2007b; Kempema et al., 2007; Kusnierczyk et al., 2008).

However, these three classical explanations do not take into account a fourth unique characteristic of both the $M$. persicae and $B$. tabaci systems: the rhizobacteria-dependent suppression of genes related to the JA/ET defensive pathways (Pineda et al., 2012; this study). In the M. persicae-A. thaliana-P. fluorescens WCS417r reported system (Pineda et al., 2012), the presence of the rhizobacteria suppressed the expression of both $A B A 1$ (ABA-signaling responsive gene) and $M Y C 2$ that were induced in plants infested with $M$. persicae, indicating a putative bacterialdependent suppression of the MYC2-branch of the JA pathway. In the same system, the PDF1.2 gene (responsive both to JA and ET) showed enhanced expression levels only at early infestation time periods (up to $24 \mathrm{~h}$ ), both in non-inoculated and

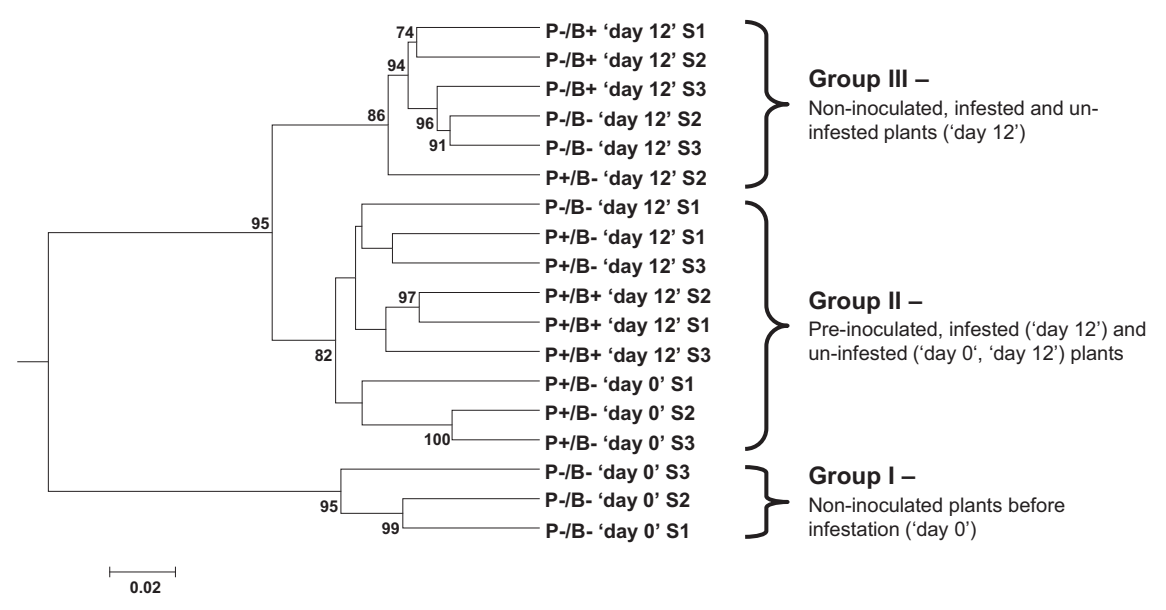

FIGURE 2 | Cluster analysis of tomato rhizosphere bacterial community patterns. DGGE patterns were aligned using Fingerprinting ${ }^{\circledR}$ II software and the samples' densitometric curves were extracted. Unweighted pair-group method with arithmetic mean (UPGMA) algorithm was applied to a Bray-Curtis distance matrix calculated between the samples densitometric curves. Numbers at the nodes represent bootstrap values performed with 10,000 replications (bootstrap values $>70$ are presented). $P-$, non-inoculated control; P+, P. fluorescens-inoculated; B+, B. tabaci-infested plants; B-, uninfested control; "day 0," prior to infestation; "day 12," 12 days after infestation. S, sample. 
pre-inoculated aphid-infested plants. It was also recently reported that application of $P$. rapae (specialist chewing insect herbivore) larval oral secretion into wounded $A$. thaliana leaf tissue stimulated the ERF-branch of the JA pathway, but feeding of the larvae activated MYC2 transcription which lowered the attractiveness of the leaf for insect feeding (Verhage et al., 2011). Collectively, these findings raise the possibility that $P$. fluorescens WCS417r pre-inoculation increases the performance of phloem-feeders by down-regulating efficient defenses related to the JA-pathway.

It is important to note, however, that the setting of our B. tabaci-tomato- $P$. fluorescens WCS417r system was somewhat different from that described for $M$. persicae, because the effects of adults ("day 1") and nymphs ("day 12") infestation were separated by collecting the adults after one day. More importantly, as $B$. tabaci eggs do not feed (the egg pedicel serves only as a conduit for water movement into the egg; Byrne et al., 1990), "day 6," in which the eggs only begin to hatch, likely served as an intermediate buffering interval, where the system was dominated by the effect of $P$. fluorescens WCS417r pre-inoculation. At this time point, significant reduced activity of both $P I-I I$ and $P R-2$ was observed in $\mathrm{P}+/ \mathrm{B}+$ (pre-inoculated, infested) plants when compared to $\mathrm{P}-/ \mathrm{B}+$ (non-inoculated, infested) plants and a similar non-significant trend was also observed in the expression pattern of $P I-I$. Interestingly, it was recently reported that Helicoverpa zea eggs triggered the expression of the PI-II gene at the ovipsotion site in tomato (Kim et al., 2012), which might partially explain the higher (although not significant) expression of $P I-I I$ in the $\mathrm{P}-/ \mathrm{B}+$ (non-inoculated, infested) treatment relative to the $\mathrm{P}-/ \mathrm{B}-$ (non-inoculated, un-infested) treatment at "day 6. " In addition, the $P I-I I$ gene also showed a marginally-significant reduced expression level in $\mathrm{P}+/ \mathrm{B}-$ (pre-inoculated, un-infested) plants when compared to $\mathrm{P}-/ \mathrm{B}-$ (non-inoculated, un-infested) plants. In tomato, the $P I-I$ gene is induced by wounding, systemin and JA treatments while PI-II requires both ET and JA signaling for its induction (Rojo et al., 2003). Moreover, the PR-2 gene can be positively regulated not only by SA but also by ET (Van Kan et al., 1995). Taken together, these findings suggest a possible down-regulation of both ET-responsive genes and JAresponsive genes (to a lesser extent) in P. fluorescens WCS417r pre-inoculated tomato plants, which is in line with a previous report of significant reduction in the expression of genes encoding ET-related transcription factors in roots of $A$. thaliana plants preinoculated with P. fluorescens WCS417r (Verhagen et al., 2004). Moreover, it was recently hypothesized that PGPR modulate host immune responses by interfering with the ET signaling pathway (Zamioudis and Pieterse, 2012). The suppressed expression pattern of the JA/ET-pathway at "day 6," the exact time when eggs hatch and young nymphs are most susceptible to plant defenses, might partially explain the better nymph performance observed on pre-inoculated plants relative to non-inoculated plants. However, it is also clear that a better characterization of the mechanisms by which $P$. fluorescens WCS417r interacts with tomato and other plants, is a prerequisite for a better understanding of the subsequent effects on the interactions of the plants with phloem-feeding insects (Pineda et al., 2013).

In contrast to the above, the expression patterns of the PI-I, $P I-I I, P R-2$, and PR-5 genes at "day 1" and "day 12" were largely affected by adult feeding/egglaying and nymph feeding, respectively, which seemed to override the PGPR repressing effect. Similar to previous findings in other Solanaceae systems (Sanchez-Hernandez et al., 2006; Estrada-Hernandez et al., 2009; Puthoff et al., 2010; Valenzuela-Soto et al., 2010; Yang et al., 2011), the response of plants to $B$. tabaci feeding, involves up-regulation of both SA- and JA/ET-responsive genes. This is in contrast to the reported changes in gene expression during $B$. tabaci infestation of $A$. thaliana, where SA-responsive genes were found to accumulate while JA/ET-responsive wound/defense genes were found to be suppressed or unchanged (Kempema et al., 2007; Zarate et al., 2007). Previously, Sanchez-Hernandez et al. (2006) has shown that nymph development of $B$. tabaci is delayed on a transgenic line that ectopically express prosystemin (35S:ProSys), while Valenzuela-Soto et al. (2010) observed enhanced nymph development on tomato spr2 (suppressor of prosystemin-mediated responses 2 ) mutants that were compromised in linolenic acid (LA) and JA synthesis. Collectively, two conclusions can be made: (I) avoiding activation of the JA/ET-response pathway in tomato would be advantageous to $B$. tabaci success; (II) in contrast to A. thaliana, tomato plants perceive $B$. tabaci infestation more like a nectrotrophic pathogen than tissue-damaging insect herbivores or biotrophic pathogens and activate the putatively "right" defensive pathways to tolerate the insect.

Besides promoting plant growth indirectly by protecting plants from diseases caused by different types of pathogens or herbivore insects, beneficial soil-borne bacteria can also promote plant growth directly. For example, Rhizobium bacteria (as well as other bacteria from related genera), establish intimate symbiotic relationship with leguminous plants that involves fixation of atmospheric nitrogen for the benefit of the plant (Spaink, 2000). Mycorrhizal fungi form symbiotic associations with the roots of the majority of herbaceous plant species in terrestrial systems. The fungus is thought to gain supply of carbon, transferred from the host plant, while the plant benefits from an enhanced nutrient uptake (Fitter, 1990). In addition, improved root development and water and mineral uptake have been widely reported in various plant species following inoculation with the PGPR Azospirillum brasilense (Fibach-Paldi et al., 2012). Although root colonization by P. fluorescens WCS417r was mostly associated with an increase in plant defensive capacity (Van Loon, 2007), our analyses indicated that the nutrient contents of tomato leaf tissues were affected by the presence of $P$. fluorescens in the rhizospere. Pre-inoculated plant leaf tissues contained significantly more soluble carbohydrates, while both $\mathrm{N}$ and $\mathrm{C}$ contents were significantly higher in non-inoculated plants. The $\mathrm{C} / \mathrm{N}$ ratios, on the other hand, were found to be similar in pre- and non-inoculated tomato plants. As a phloemfeeder, B. tabaci ingests a diet that is rich in soluble carbohydrates (Hendrix et al., 1992). Although it is unlikely that soluble carbohydrates concentrations were a limiting factor in our system, their $15 \%$ increase in pre-inoculated plants, might have changed the insect's diet from "rich" to "richer," partially explaining the better nymph performance on these plants. On the other hand, plant phloem sap is generally considered to be limited in $\mathrm{N}$ (Byrne and Miller, 1990). However, B. tabaci and other phloem-feeding insects, such as aphids, were shown to excrete amino acids 
(Isaacs et al., 1998). Moreover, B. tabaci can rapidly sense and metabolically adjust to altered plant $\mathrm{N}$ status (Crafts-Brandner, 2002). As the tomato plants in our system were well fertilized, we find it improbable that the differences found in $\mathrm{N}$ content between pre-inoculated and non-inoculated plants, affected the insect's developmental performance. Moreover, no significant differences were detected in the $\mathrm{N}$ and $\mathrm{C}$ contents and their $\mathrm{C} / \mathrm{N}$ ratio, between $B$. tabaci adults that fed for 6 days on pre- or non-inoculated tomato plants. Similarly, M. persicae exhibited improved growth and reproduction on Plantago lanceolata plants infected with arbuscular mycorrhizal fungi, despite the fact that the plants had lower N contents (Gange and West, 1994). The higher $\mathrm{C}$ and $\mathrm{N}$ contents in non-inoculated plants could also lead to an increase in the production of nitrogen- and carbon-based plant defenses. However, this possibility was not further explored in our study.

Last, we tested whether the enhanced performance of $B$. tabaci on $P$. fluorescens WCS417r pre-inoculated tomato plants could be associated with the ability of the rhizobacteria to affect the soil bacterial community. Both the ANOSIM and cluster analyses, performed on the densitometric curves of the DGGE profiles, indicated a significant effect on the rhizosphere bacterial community, for the presence of the bacteria, and a high similarity between pre-inoculated plant samples, regardless of their infestation state or the length of the infestation period. It is important to clarify that although in these experiments, we used sterilized soil, the experiments were not performed under sterile conditions. Therefore, it is likely that under the experimental conditions, rhizosphere bacteria arrived with the seeds (and with seedlings upon transfer to pots), or from both irrigation water and air. Since we used a sterilized soil, bacteria coming from these sources could highly proliferate during the experiment, due to the biological vacuum caused by soil sterilization. Beneficial rhizobacteria can manipulate the plant's

\section{REFERENCES}

Abd El Rahman, T., El Oirdi, M., Gonzalez-Lamothe, R., and Bouarab, K. (2012). Necrotrophic pathogens use the salicylic acid signaling pathway to promote disease development in tomato. Mol. Plant Microbe Interact. 25, 1584-1593. doi: 10.1094/MPMI-07-12-0187-R

Ahn, I. P., Lee, S. W., and Suh, S. C. (2007). Rhizobacteria-induced priming in Arabidopsis is dependent on ethylene, jasmonic acid, and NPR1. Mol. Plant Microbe Interact. 20, 759-768. doi: 10.1094/MPMI20-7-0759

Baldwin, I. T. (2001). An ecologically motivated analysis of plant-herbivore interactions in native tobacco. Plant Physiol. 127, 1449-1458. doi: 10.1104/pp.010762

Baldwin, I. T., and Preston, C. A. (1999). The eco-physiological complexity of plant responses to insect herbivores. Planta 208, 137-145. doi: $10.1007 / \mathrm{s} 004250050543$
Bari, R., and Jones, J. D. G. (2009). Role of plant hormones in plant defence responses. Plant Mol. Biol. 69, 473-488. doi: 10.1007/s11103008-9435-0

Bostock, R. M. (2005). Signal crosstalk and induced resistance: straddling the line between cost and benefit. Annu. Rev. Phytopathol. 43, 545-580. doi: 10.1146/annurev. phyto.41.052002.095505

Byrne, D. N., Cohen, A. C., and Draeger, E. A. (1990). Water uptake from plant tissue by the egg pedicel of the greenhouse whitefly, Trialeurodes vaporariorum (Westwood) (Homoptera: Aleyrodidae). Can. J. Zool. 68, 1193-1195. doi: 10.1139/z90-177

Byrne, D. N., and Miller, W. B. (1990). Carbohydrate and amino acid composition of phloem sap and honeydew produced by Bemisia tabaci. J. Insect Physiol. 36, 433-439. doi: 10.1016/0022-1910 (90)90061-J

microbiome by suppressing the activity of pathogenic and nonpathogenic microorganisms not only by activating ISR but also through microbial antagonism (Van Loon, 2007). This is largely achieved by mechanisms such as competition for both nutrients and space and antibiosis through the production of specific and non-specific microbial metabolites, lytic enzymes, volatile compounds or other microbial toxins (Haas and Defago, 2005; Doornbos et al., 2012). However, the net effect of these belowground interactions on the plant's nutritional quality and defense status above-ground, and their direct impact on phloem-feeders longevity, fecundity and nymph development is yet to be determined.

In conclusion, the development of environmentally friendly pest control tactics that are based on soil beneficial organisms can extend the range of options for maintaining the health and yield of crops. PGPR inoculants (Azospirillum, Bacillus, Pseudomonas, etc.) are now available for a variety of crops (Hayat et al., 2010; Helman et al., 2011). Moreover, previous studies on $P$. fluorescens have established that soil inoculation can give protection against several important lepidopteran agricultural pests (Pineda et al., 2010), making the technology a future "green" alternative strategy to chemical insecticides. Our findings, however, suggest that the technology might not be applicable for controlling phloem-feeding pests, which are expected to benefit from its implementation into agricultural systems.

\section{ACKNOWLEDGMENTS}

This project was funded by a grant from the Agriculture, Environment and Natural Resources Center of the Robert H. Smith Faculty of Agriculture, Food and Environment, The Hebrew University of Jerusalem, and by a grant from the Program of Proposals for Minerva's Centers. We thank Prof. Peter Bakker (Universiteit Utrecht) for providing us P. fluorescens WCS417r.

Crafts-Brandner, S. J. (2002). Plant nitrogen status rapidly alters amino acid metabolism and excretion in Bemisia tabaci. J. Insect Physiol. 48, 33-41. doi: 10.1016/S0022-1910(01)00140-8

De Vos, M., Van Oosten, V. R., Jander, G., Dicke, M., and Pieterse, C. M. J. (2007a). Plants under attack: multiple interactions with insects and microbes. Plant Signal. Behav. 2, 527-529. doi: 10.4161/psb. 2.6.4663

De Vos, M., Kim, J. H., and Jander, G. (2007b). Biochemistry and molecular biology of Arabidopsis-aphid interactions. Bioessays 29, 871-883. doi: 10.1002/bies.20624

Dombrecht, B., Xue, G. P., Sprague, S. J., Kirkegaard, J. A., Ross, J. J., Reid, J. B., et al. (2007). MYC2 differentially modulates diverse jasmonate-dependent functions in Arabidopsis. Plant Cell 19, 2225-2245. doi: 10.1105/tpc.106.048017
Doornbos, R. F., Van Loon, L. C., and Bakker, P. A. H. M. (2012). Impact of root exudates and plant defense signaling on bacterial communities in the rhizosphere. Agron. Sustain. Dev. 32, 227-243. doi: 10.1007/s13593-011-0028-y

Durrant, W. E., and Dong, X. (2004). Systemic acquired resistance. Annu. Rev. Phytopathol. 42, 185-209. doi: $10.1146 /$ annurev.phyto.42. 040803.140421

Elsayed, G. (2011). Plant secondary substances and insects behaviour. Arch. Phytopathol. Plant Prot. 44, 1534-1549. doi: 10.1080/03235408.2010.507957

Estrada-Hernandez, M. G., ValenzuelaSoto, J. H., Ibarra-Laclette, E., and Delano-Frier, J. P. (2009). Differential gene expression in whitefly Bemisia tabaci-infested tomato (Solanum lycopersicum) plants at progressing developmental stages of the insect's life cycle. Physiol. Plant 137, 
44-60. doi: 10.1111/j.1399-3054. 2009.01260.x

Fibach-Paldi, S., Burdman, S., and Okon, Y. (2012). Key physiological properties contributing to rhizosphere adaptation and plant growth promotion abilities of Azospirillum brasilense. FEMS Microbiol. Lett. 326, 99-108. doi: 10.1111/j.15746968.2011.02407.x

Fitter, A. H. (1990). The role and ecological significance of vesiculararbuscular mycorrhizas in temperate ecosystems. Agric. Ecos. Env. 29, 137-151. doi: 10.1016/01678809(90)90268-I

Gange, A. C., and West, H. M. (1994). Interactions between arbuscular mycorrhizal fungi and foliar-feeding insects in Plantago lanceolata L. New Phytol. 128, 79-87. doi: 10.1111/j.14698137.1994.tb03989.x

Gehring, C., and Bennett, A. (2009). Mycorrhizal fungal-plant-insect interactions: the importance of a community approach. Environ. Entomol. 38, 93-102. doi: 10.1603/022.038.0111

Glazebrook, J. (2005). Contrasting mechanisms of defense against biotrophic and necrotrophic pathogens. Annu. Rev. Phytopathol. 43, 205-227. doi: 10.1146/annurev. phyto.43.040204.135923

Green, S. J., Leigh, M. B., and Neufeld, J. D. (2009). "Denaturing gradient gel electrophoresis (DGGE) for microbial community analysis," in Microbiology of Hydrocarbons, Oils, Lipids, and Derived Compounds, ed K. N. Timmis (Heidelberg: Springer), 4137-4158.

Haas, D., and Defago, G. (2005). Biological control of soil-borne pathogens by fluorescent pseudomonads. Nat. Rev. Microbiol. 3, 307-319. doi: 10.1038/ nrmicrol129

Hayat, R., Ali, S., Amara, U., Khalid, R., and Ahmed, I. (2010). Soil beneficial bacteria and their role in plant growth promotion: a review. Ann. Microbiol. 60, 579-598. doi: 10.1007/s13213010-0117-1

Heil, M., and Walters, D. (2009). Ecological consequences of plant defence signaling. Adv. Bot. Res. 51, 667-716. doi: 10.1016/S00652296(09)51015-4

Helman, Y., Burdman, S., and Okon, Y. (2011). "Plant growth promotion by rhizosphere bacteria through direct effects," in Beneficial Microorganisms in Multicellular Life Forms, eds E. Rosenberg and U. Gophna (Berlin: Springer-Verlag), 89-103.
Hendrix, D. L., Wei, Y., and Leggett, J. E. (1992). Homopteran honeydew sugar composition is determined by both insect and plant species. Comp. Biochem. Physiol. 101B, 23-27.

Howe, G. A., and Jander, G. (2008). Plant immunity to insect herbivores. Annu. Rev. Plan. Biol. 59, 41-66. doi: 10.1146/annurev. arplant.59.032607.092825

Isaacs, R., Byrne, D. N., and Hendrix, D. L. (1998). Feeding rates and carbohydrate metabolism by Bemisia tabaci (Homoptera: Aleyrodidae) on different quality phloem saps. Physiol. Entomol. 23, 241-248. doi: 10.1046/j.1365-3032.1998.233080.x

Johnson, D. D., and Walker, G. P. (1999). Intracellular punctures by the adult whitefly Bemisia argentifolii on DC and AC electronic feeding monitors. Entomol. Exp. Appl. 92, 257-270. doi: 10.1046/j.15707458.1999.00545.x

Kaloshian, I., and Walling, L. L. (2005). Hemipterans as plant pathogens. Annu. Rev. Phytopathol. 43, 491-521. doi: 10.1146/annurev. phyto.43.040204.135944

Kazan, K., and Manners, J. M. (2008). Jasmonate signaling: toward an integrated view. Plant Physiol. 146, 1459-1468. doi: 10.1104/pp.107.115717

Kempema, L. A., Cui, X., Holzer, F. M., and Walling, L. L. (2007). Arabidopsis thaliana transcriptome changes in response to phloem-feeding silverleaf whitefly nymphs: similarities and distinctions in responses to aphids. Plant Physiol. 143, 849-865. doi: 10.1104/pp.106.090662

Kessler, A., and Baldwin, I. T. (2002). Plant responses to insect herbivory: the emerging molecular analysis. Annu. Rev. Plant Biol. 53, 299-328. doi: $\quad 10.1146 /$ annurev.arplant.53. 100301.135207

Khasdan, V., Levin, I., Rosner, A., Morin, S., Kontsedalov, S., Maslenin, I., et al. (2005). DNA markers for identifying biotypes $\mathrm{B}$ and $\mathrm{Q}$ of Bemisia tabaci and studying population dynamics. Bull. Entomol. Res. 95, 605-613. doi: 10.1079/BER2005390

Kim, J., Tooker, J. F., Luthe, D. S., De Moraes, C. M., and Felton, G. W. (2012). Insect eggs can enhance wound response in plants: a study system of tomato Solanum lycopersicum L. and Helicoverpa zea Boddie. PLoS ONE 7:e37420. doi: 10.1371/journal.pone.0037420

King, E. O., Ward, M. K., and Raney, D. E. (1954). Two simple media for the demonstration of pyocyanin and fluorescin. J. Lab. Clin. Med. 44, 301-307.

Koricheva, J., Gange, A. C., and Jones, T. (2009). Effects of mycorrhizal fungi on insect herbivores: a metaanalysis. Ecology 90, 2088-2097. doi: 10.1890/08-1555.1

Kunkel, B. N., and Brooks, D. M. (2002). Cross talk between signaling pathways in pathogen defense. Curr. Opin. Plant Biol. 5, 325-331. doi: 10.1016/S1369-5266 (02)00275-3

Kusnierczyk, A., Winge, P., Jorstad, T. S., Troczynka, J., Rossiter, J. T., and Bones, A. M. (2008). Towards global understanding of plant defence against aphids - timing and dynamics of early Arabidopsis defence responses to cabbage aphid (Brevicoryne brassicae) attack. Plant Cell Environ. 31, 1097-1115. doi 10.1111/j.1365-3040.2008.01823.x

Lorenzo, O., Chico, J. M., SanchezSerrano, J. J., and Solano, R. (2004). Jasmonate-insensitive 1 encodes a MYC transcription factor essential to discriminate between different jasmonate regulated defence responses in Arabidopsis. Plant Cell 16, 1938-1950. doi: 10.1105/tpc.022319

Lorenzo, O., and Solano, R. (2005). Molecular players regulating the jasmonate signalling network. Curr. Opin. Plant Biol. 8, 532-540. doi: 10.1016/j.pbi.2005.07.003

Lorenzo, O., Piqueras, R., SanchezSerrano, J. J., and Solano, R. (2003). ETHYLENE RESPONSE FACTOR1 integrates signals from ethylene and jasmonate pathways in plant defense. Plant Cell 15, 165-178. doi 10.1105/tpc.007468

Mascia, T., Santovito, E., Gallitelli, D. and Cillo, F. (2010). Evaluation of reference genes for quantitative reverse-transcription polymerase chain reaction normalization in infected tomato plants. Mol. Plant Pathol. 11, 805-816.

Navas-Castillo, J., Fiallo-Olivé, and E., and Sánchez-Campos, S. (2011). Emerging virus diseases transmitted by whiteflies. Annu. Rev. Phytopathol. 49, 219-248. doi: $\quad$ 10.1146/annurev-phyto072910-095235

Oliveira, M. R. V., Henneberry, T. J., and Anderson, P. (2001). History, current status and collaborative research projects for Bemisia tabaci. Crop Prot. 20, 709-723. doi: 10.1016/S0261-2194(01)00108-9

Pieterse, C. M. J., Leon-Reyes, A., Van der Ent, S., and Van Wees, S. C. M. (2009). Networking by small-molecules hormones in plant immunity. Nat.
Chem. Biol. 5, 308-316. doi: 10.1038/nchembio.164

Pieterse, C. M. J., Van Wees, S. C. M., Hoffland, E., Van Pelt, J. A., and Van Loon, L. C. (1996). Systemic resistance in Arabidopsis induced by biocontrol bacteria is independent of salicylic acid accumulation and pathogenesis-related gene expression. Plant Cell 8, 1225-1237.

Pieterse, C. M. J., Van Wees, S. C. M., Van Pelt, J. A., Knoester, M., Laan, R., Gerrits, H., et al. (1998). A novel signaling pathway controlling induced systemic resistance in Arabidopsis. Plant Cell 10, 1571-1580.

Pineda, A., Dicke, M., Pieterse, C. M. J., and Pozo, M. J. (2013). Beneficial microbes in a changing environment: are they always helping plants to deal with insects? Funct. Ecol. 27, 574-586. doi: 10.1111/13652435.12050

Pineda, A., Zheng, S. J., Van Loon, J. J. A., and Dicke, M. (2012). Rhizobacteria modify plant-aphid interactions: a case of induced systemic susceptibility. Plant Biol. 14(Suppl. 1), 83-90. doi: 10.1111/j.1438-8677.2011.00549.x

Pineda, A., Zheng, S. J., Van Loon, J. J. A., Pieterse, C. M. J., and Dicke, M. (2010). Helping plants to deal with insects: the role of beneficial soil-borne microbes. Trends Plant Sci. 15, 507-514. doi: 10.1016/j.tplants.2010.05.007

Puthoff, D. P., Holzer, F. M., Perring, T. M., and Walling, L. L. (2010). Tomato pathogenesis-related protein genes are expressed in response to Trialeurodes vaporariorum and Bemisia tabaci Biotype B feeding. J. Chem. Ecol. 36, 1271-1285. doi 10.1007/s10886-010-9868-

Ramsey, J. S., Rider, D. S., Walsh, T. K., De Vos, M., Gordon, K. H. I., Ponnala, L., et al. (2010). Comparative analysis of detoxification enzymes in Acyrthosiphon pisum and Myzus persicae. Insect Mol. Biol. 19, 155-164. doi: 10.1111/j.1365-2583.2009.00973.x

Rojo, E., Leon, J., and Sanchez-Serrano, J. J. (1999). Cross-talk between wound signalling pathways determines local versus systemic gene expression in Arabidopsis thaliana. Plant J. 20, 135-142. doi: 10.1046/j. 1365-313x.1999.00570.x

Rojo, E., Solano, R., and SanchezSerrano, J. J. (2003). Interactions between signaling compounds involved in plant defense. J. Plant Growth Regul. 22, 82-98. doi: 10.1007/s00344-003-0027-6

Sanchez-Hernandez, C., Lopez, M. G., and Delano-Frier, J. P. 
(2006). Reduced levels of volatile emissions in jasmonate-de?cient spr2 tomato mutants favour oviposition by insect herbivores. Plant Cell Environ. 29, 546-557. doi: 10.1111/j.1365-3040. 2005.01431.x

Schuster, D. J., Stansly, P. A., and Polston, J. E. (1996). "Expressions of plant damage by Bemisia," in Bemisia 1995 Taxonomy, Biology, Damage Control and Management, eds D. Gerling D and R. T. Mayer (Andover: Intercept Ltd.), 153-165.

Spaink, H. P. (2000). Root nodulation and infection factors produced by rhizobial bacteria. Annu. Rev. Microbiol. 54, 257-288. doi: 10.1146/annurev.micro.54.1.257

Tjallingii, W. F., and Esch, T. H. (1993). Fine-structure of aphid stylet routes in plant-tissues in correlation with EPG signals. Physiol. Entomol. 18, 317-328. doi: 10.1111/j.13653032.1993.tb00604.x

Valenzuela-Soto, J. H., EstradaHernandez, M. G., Ibarra-Laclette, E., and Delano-Frier, J. P. (2010). Inoculation of tomato plants (Solanum lycopersicum) with growth-promoting Bacillus subtilis retards whitefly Bemisia tabaci development. Planta 231, 397-410. doi: 10.1007/s00425-009-1061-9

Van Kan, J. A. L., Cozijnsen, T., Danhash, N., and De Wit, P. J. G. M. (1995). Induction of tomato stress protein mRNAs by ethephon, 2,6dichloroisonicotinic acid and salicylate. Plant Mol. Biol. 27, 1205-1213. doi: 10.1007/BF00020894

Van Loon, L. C. (2007). Plant responses to plant growth-promoting rhizobacteria. Eur. J. Plant Pathol. 119, 243-254. doi: 10.1007/s10658-0079165-1

Van Loon, L. C., Bakker, P. A. H. M., and Pieterse, C. M.
J. (1998). Systemic resistance induced by rhizosphere bacteria. Annu. Rev. Phytopathol. 36, 453-483. doi: 10.1146/annurev. phyto.36.1.453

Van Loon, L. C., Rep, M., and Pieterse, C. M. (2006). Significance of inducible defense-related proteins in infected plants. Annu. Rev. Phytopathol. 44, 135-162. doi: $\quad 10.1146 /$ annurev.phyto.44. 070505.143425

Van Loon, L. C., and Van Strien, E. A. (1999). The families of pathogenesis-related proteins, their activities, and comparative analysis of PR-1 type proteins. Physiol. Mol. Plant Pathol. 55, 85-97. doi: 10.1006/pmpp.1999.0213

Van Oosten, V. R., Bodenhausen, N. Reymond, P., Van Pelt, J. A., Van Loon, L. C., Dicke, M., et al. (2008). Differential effectiveness of microbially induced resistance against herbivorous insects in Arabidopsis. Mol. Plant Microbe Interact. 21, 919-930. doi: 10.1094/MPMI-21-70919

Verhage, A., Vlaardingerbroek, I., Raaymakers, C., Van Dam, N. Dicke, M., Van Wees, S. C. M. et al. (2011). Rewiring of the jasmonate signaling pathway in Arabidopsis during insect herbivory. Front. Plant Sci. 2, 47. doi: 10.3389/fpls.2011.00047

Verhagen, B. W. M., Glazebrook, J., Zhu, T., Chang, H.-S., Van Loon, L. C., and Pieterse, C. M. J. (2004). The transcriptome of rhizobacteriainduced systemic resistance in Arabidopsis. Mol. Plant Microbe Interact. 17, 895-908. doi: 10.1094/MPMI.2004. 17.8.895

Walker, G. P., and Perring, T. M. (1994). Feeding and oviposition behavior of whiteflies (Homoptera: Aleyrodidae) interpreted from Ac electronic feeding monitor waveforms. Ann. Entomol. Soc. Am. 87 363-374.

Walling, L. L. (2000). The myriad plant responses to herbivores. J. Plant. Growth. Regul. 19, 195-216.

Walling, L. L. (2008). Avoiding effective defenses: strategies employed by phloem-feeding insects. Plant Physiol. 146, 859-866. doi: 10.1104/pp.107.113142

Ward, E. R., Uknes, S. J., Williams, S. C., Dinsher, S. S., Wiederhold, D. L., Alexander, D. C., et al. (1991). Coordinate gene activity in response to agents that induce systemic acquired resistance. Plant Cell 3, 1085-1094.

Wu, J., and Baldwin, I. T. (2010) New insights into plant responses to the attack from insect herbivores. Annu. Rev. Genet. 44, 1-24. doi: 10.1146/annurev-genet102209-163500

Yang, J. W., Yi, H.-S., Kim, H., Lee, B. Lee, S., Ghim, S.-Y., et al. (2011). Whitefly infestation of pepper plants elicits defence responses against bacterial pathogens in leaves and roots and changes the belowground microflora. J. Ecol. 99, 46-56. doi: 10.1111/j.1365-2745 2010.01756.x

Yemm, E. W., and Willis, A. J. (1954). The estimation of carbohydrates in plant extracts by anthrone. Biochem. J. 57, 508-514.

Yuan, J. S., Reed, A., Chen, F., and Stewart, C. N. (2006). Statistical analysis of real-time PCR data. BMC Bioinformatics 7:85. doi: 10.1186/1471-2105-7-85

Zamioudis, C., Pieterse, C. M. J. (2012). Modulation of host immunity by beneficial microbes. Mol. Plant Microbe Interact. 25, 139-150. doi: 10.1094/MPMI06-11-0179
Zarate, S. I., Kempema, L. A., and Walling, L. L. (2007). Silverleaf whitefly induces salicylic acid defenses and suppresses effectual jasmonic acid defenses. Plant Physiol. 143, 866-875. doi: 10.1104/pp.106.090035

Zhu-Salzman, K., Salzman, R. A. Ahn, J. E., and Koiwa, H. (2004). Transcriptional regulation of sorghum defense determinants against a phloem-feeding aphid. Plant Physiol. 134, 420-431. doi: $10.1104 /$ pp.103.028324

Conflict of Interest Statement: The authors declare that the research was conducted in the absence of any commercial or financial relationships that could be construed as a potential conflict of interest.

Received: 13 May 2013; accepted: 22 July 2013; published online: 13 August 2013.

Citation: Shavit R, Ofek-Lalzar M, Burdman S and Morin S (2013) Inoculation of tomato plants with rhizobacteria enhances the performance of the phloem-feeding insect Bemisia tabaci. Front. Plant Sci. 4:306. doi: 10.3389/fpls.2013.00306

This article was submitted to Frontiers in Plant-Microbe Interaction, a specialty of Frontiers in Plant Science.

Copyright (c) 2013 Shavit, Ofek-Lalzar, Burdman and Morin. This is an openaccess article distributed under the terms of the Creative Commons Attribution License (CC BY). The use, distribution or reproduction in other forums is permitted, provided the original author(s) or licensor are credited and that the original publication in this journal is cited, in accordance with accepted academic practice. No use distribution or reproduction is permitted which does not comply with these terms. 


\section{APPENDIX}

Table A1 | Quantitative real-time PCR (qRT-PCR) and denaturing gradient gel electrophoresis (DDGE) list of forward (F) and reverse (R) primers and PCR product sizes.

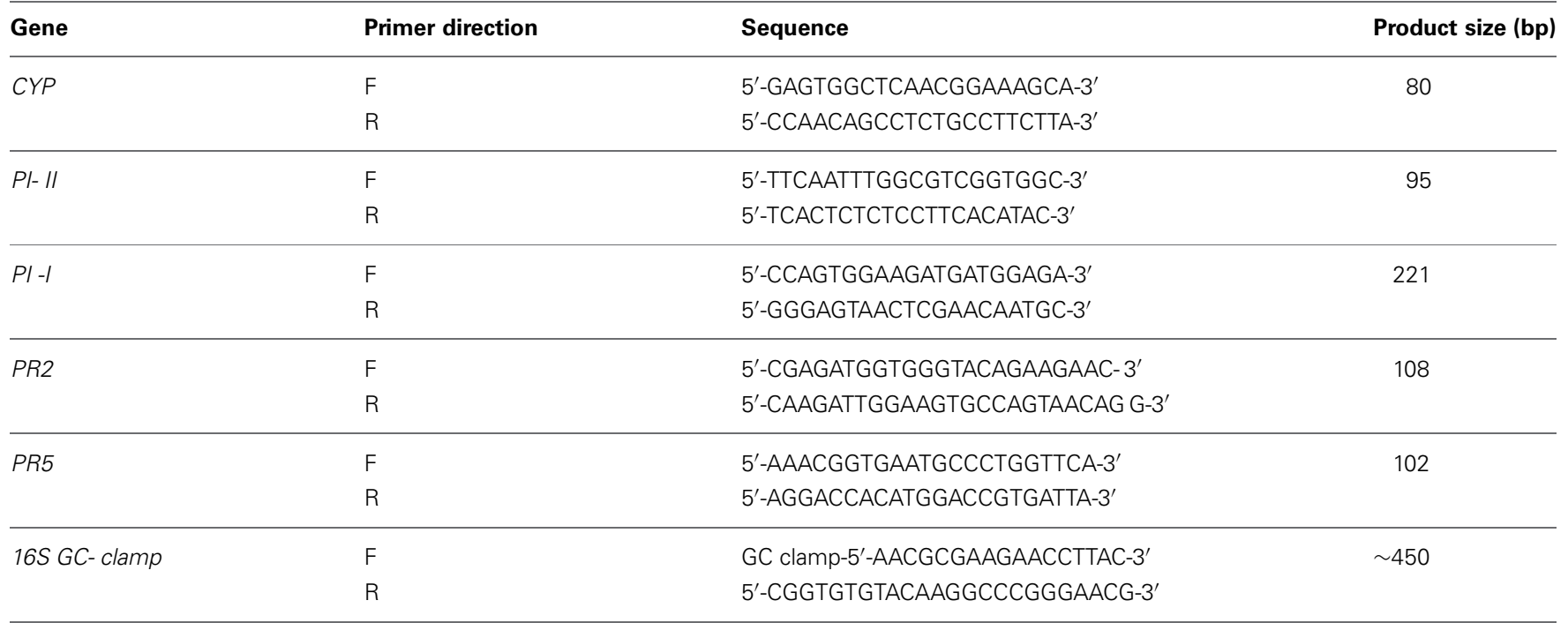

Table A2 | ANOVA results ( $F$-values and significance) of quantitative real-time PCR (qRT-PCR) analyses (main effects).

\begin{tabular}{|c|c|c|c|c|c|c|c|c|}
\hline Source & \multicolumn{2}{|c|}{$P I-I$} & \multicolumn{2}{|c|}{$P I-I I$} & \multicolumn{2}{|c|}{$P R-2$} & \multicolumn{2}{|c|}{$P R-5$} \\
\hline "Bacteria" & $3.55_{(1,82)}$ & 0.063 & $4.40_{(1,80)}$ & $0.039 *$ & $4.57_{(1,73)}$ & $0.036^{*}$ & $4.37_{(1,81)}$ & $0.040^{*}$ \\
\hline "Time" & $5.79_{(2,82)}$ & $0.004^{*}$ & $3.45_{(2,80)}$ & $0.036^{*}$ & $16.53_{(2,73)}$ & $<0.0001 *$ & $8.53_{(2,81)}$ & $0.0004^{*}$ \\
\hline "Insect Infestation" & $0.050_{(1,82)}$ & 0.824 & $7.47^{*}(1,80)$ & $0.008^{*}$ & $2.63_{(1,73)}$ & 0.110 & $1.04_{(1,81)}$ & 0.311 \\
\hline
\end{tabular}

See Material and Methods for detailed description of applied model. Asterisks indicate statistical significance $(P \leq 0.05)$. 